Оја Кринуловић

Миле Стијеповић

Универзитетска библиотека

"Светозар Марковић“, Београд
UDC: 02:004.738.5

DOI: $10.18485 /$ dh.2015.1.ch11

\title{
ДИГИТАЛНЕ БИБЛИОТЕКЕ - БИБЛИОТЕКЕ БУДУЋНОСТИ
}

\section{Сажетак}

Дигиталне библиотеке представљају једну од најактуелнијих тема за расправу о будућности библиотека у 21. веку. Значајан број водећих светских библиотека је дигитализовао многе вредне збирке из својих фондова.

С обзиром на брз развој дигиталних библиотека, намеће се питање опстанка традиционалних библиотека. Постоји група теоретичара која сматра да ће данашње библиотеке потпуно ишчезнути и да ће бити замењене виртуелним дигиталним библиотекама које су доступне 24 часа дневно 7 дана у недељи путем Интернета. То би значило да библиотеке потпуно промене своју функцију и облик и од „куће знања“ прерасту у „море информација“. Главна идеја светских библиотека је да своје електронске дигиталне збирке стави на располагање путем Интернета, како би биле доступне широм света сваком кориснику, и то углавном бесплатно.

Универзитетска библиотека „Светозар Марковић“ у Београду се такође прудружила процесу дигитализације. Прво је дигитализована збирка рукописа из заоставштине српске књижевнице Исидоре Секулић, а затим стари ћирилски рукописи. Осим тога формиран је дигитални репозиторијум Универзитета у Београду - Phaidra, дат је велики допринос у међународним пројектима који је крунисан дигитализацијом старих српских новина у оквиру Europeana Newspapers пројекта у коме је Универзитетска библиотека доставила метаподатке за око 400.000 дигитализованих новинских страница на ћириличном писму.

Све развијене земље теже да своје богате библиотечке фондове дигитализују и учине доступнијим што већем броју корисника. Упркос ограниченим материјалним ресурсима, у библиотекама Србије се улаже све више напора ради укључивања у те нове трендове и доступности свеопштег културног блага човечанства.

Кључне речи: дигиталне библиотеке, дигитализација, електронске књиге, Универзитетска библиотека „Светозар Марковић“, библиотеке будућности 


\section{Увод}

Комуникација на даљину све више постаје тренд данашњег друштва.

Приступ дигиталном документу је прво о чему библиотекари морају размишљати када је реч о дигитализацији књижне грађе, јер је слободан приступ фонду библиотеке, најбоље решење за њене кориснике.

Дигитализација библиотечке грађе је довела до парадигме библиотекара који се морају суочити са низом изазова које носи будућност дигиталног документа, развој нове технологије, креирање дигиталне библиотеке, очување дигиталне грађе, а пре свега обезбеђивање финансијских средстава.

\section{Развој нових технологија и процес дигитализације}

На промену парадигме библиотекара велики утицај су имале нове технологије, при чему су библиотекари уочили да је дигитално окружење, као што су Интернет и разне друштвене мреже постало конкуренција библиотекама и библиотекарима у 21. веку. Једино сигурну будућност библиотекара у библиотекама може да обезбеди прилагођавање новим технологијама. У прилици смо да градимо једну другачију библиотеку 21.века, при чему ће та библиотека, као најуређенији систем, са претраживачима и онлајн каталозима бити у могућности да се супротстави хаотичности Интернета. Међутим, све бржи развој технологија захтева и све већу упућеност и знање библиотекара, као и праћење промена које настају развојем нових технологија. Основа је пре свега у подробнијем и озбиљнијем упознавању библиотекара са начином креирања и структуирања дигиталних библиотека, као и њиховог одржавања у будућности , а то зависи од знања из области информатичких наука. Све говори у прилог томе да будућност образовања библиотекара иде у правцу информатичких наука.

При избору грађе за дигитализацију, бира се она грађа која је у јавном власништву и за коју не постоје ауторска права. Посебан сег- 
мент у креирању дигиталне библиотеке заузимају правна питања и сагласности које се односе на ауторска права. Чињеница је да се не могу уврстити сви дигитални документи у дигиталну библиотеку због ауторских права. Све то доводи до повећања сложености задатака и обавеза библиотекара. У почетку дигитализације, библиотека се мора определити за онај део грађе који је у јавном власништву и за који не постоје ауторска права, што је случај са старијом грађом.

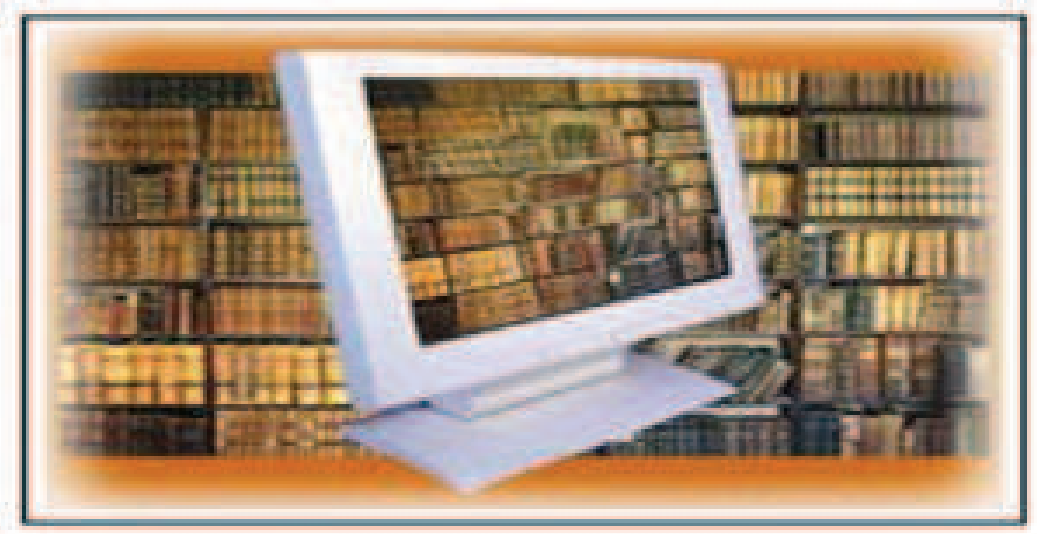

\section{Дигиталне библиотеке}

Традиционалне библиотеке су биле усмерене на набавку, чување и организацију информација.Библиотеке су набављале документа, чувале их и каталогизирале како би могли да буду пронађени и коришћени. Организација је кључни елемент и у новим дигиталним библиотекама и то је управо онај елемент који било коју другу колекцију докумената разликује од библиотечке колекције. Уколико не постоји организација, документ не може да буде пронађен, тако да не може ни да се користи. Суштина је да библиотеке више нису места на којима се могу физички пронаћи сви жељени документи, већ пре портали преко којих је могуће приступити различитим информационим ресурсима.

Добра организација електронских информационих ресурса подразумева и усвајање одговарајућих стандарда и такозваних „метадата података“. Уколико библиотека жели да изгради трајну колекцију 
квалитетних електронских извора, подаци о складиштењу тих извора морају да буду бројни и квалитетни, актуелни и погодни за даљњи развој, приступачни и структурирани у одређеним стандардним форматима. Метадата подаци, односно подаци о подацима, од суштинског су значаја за изградњу дигиталне библиотеке и готово да су исто толико значајни колико и сами подаци.

\section{Конгресна библиотека - Вашингтон}

Конгресна библиотека је у свом пројекту Националне дигиталне библиотеке истакла три типа метадата података значајних за дигиталне колекције:

1. интелектуални метадата подаци-каталошки записи, помоћни алати и различити модели претраживања

2. структурални метадата подаци - информације које повезују дигиталне објекте како би било могуће њихово логично јединство, попут чланака из часописа или архивских целина

3. административни метадата подаци -који омогућавају управљање дигиталним колекцијама, укључујући и податке о методама скенирања, резолуцији, формату дигиталног документа и његов назив.

Метадата подаци од кључног су значаја у дигиталном свету. Свако ко има намеру да креира, имплементира и управља дигиталном библиотеком, мора да има у виду те податке.

У свету, процес дигитализације се у великој мери примењује. Водеће светске националне библиотеке већ имају велике колекције дигиталних докумената. Оне својим корисницима нуде исти документ и у штампаној и у дигиталној форми, а корисник одлучује за који тип документа ће се определити. Многе дигиталне колекције, доступне су и преко Интернета. Међутим, изузетно је значајно што су управо највеће светске националне библиотеке прве увиделе све предности заједничких пројеката дигитализације, сарадње и размене докумената, не само на националном, већ и на интернационалном нивоу.

У данашњем дигиталном свету готово да нема боље теорије о библиотекама, или боље објашњене улоге библиотекара, од оне коју 
су дали Крафорд и Горман (познати библиотекари и писци многих књига о библиотекарству) у својој књизи „Будуће библиотеке: сан, лудост или стварност“. Понудили су нам пет нових закона о библиотекарству, настојећи да објасне Рангтанове принципе . Рангтан је познати индијски мислилац и велики теоретичар библиотека.

Рангтанови принципи се заснивају на следећем:

1. Библиотеке служе човечанству

2. Поштујте све облике у којима се знање појављује и преноси

3. Користите технологију интелигентно, како бисте побољшали услуге

4. Штитите право слободног приступа знању

5. Поштујте прошлост, креирајте будућност

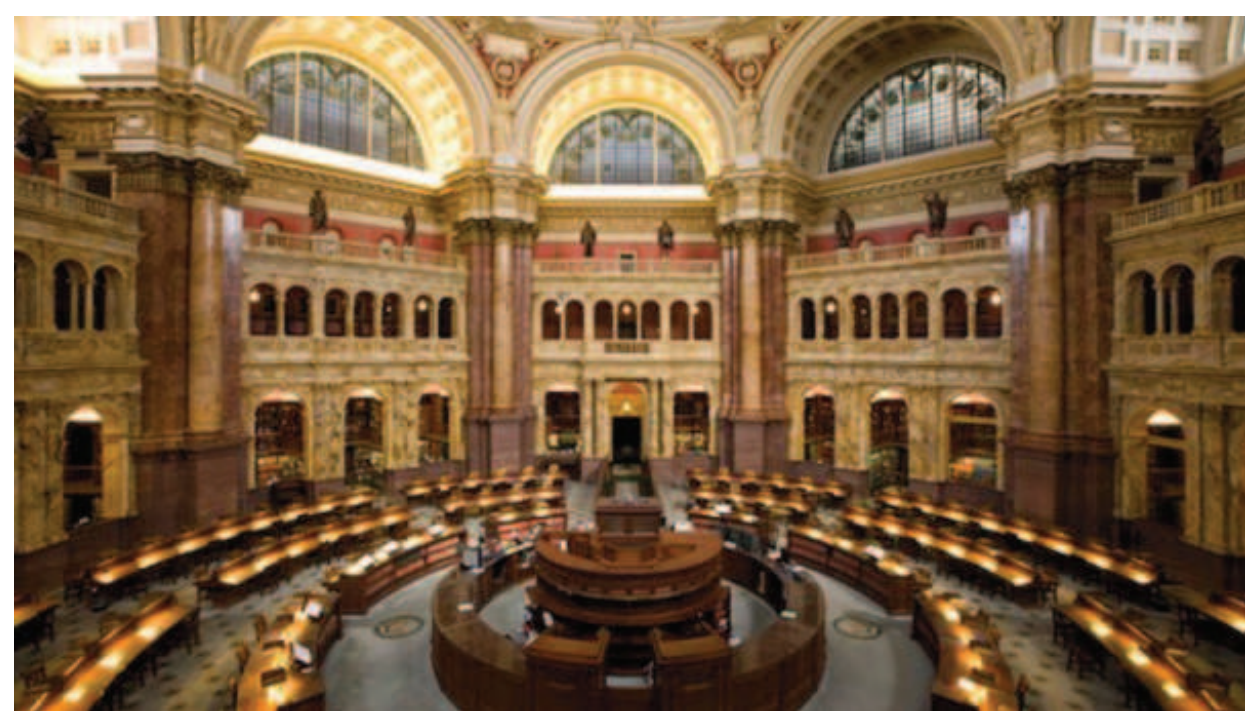

Француска национална библиотека - Париз

На тему развоја дигиталних збирки, може се рећи да Француска национална библиотека поседује највећу збирку дигиталних докумената у целој Европи. Дигитализација збирки, односно претварање стандардних штампаних публикација у публикације читљиве путем 
рачунара, пројекат је који библиотека развија и унапређује већ више од 8 година. Дигитализују се текстови, то јест књиге, али и слике и звучни записи. Библиотека је до сада дигитализовала око 100.000 књига (укупно око 30 милиона страница текста) и 300.000 слика. Избор докумената који су дигитализовани и у целости доступни преко рачунара извршен је још 1994. године. То су углавном документи који се налазе у фондовима библиотеке и доступни су корисницима путем Интернета.

На сајту библиотеке могућ је слободан приступ хиљадама дигитализованих средњевековних рукописних гравира и бакрореза, као и збирци Gallica која садржи око 25000 слика и 2500 томова текстова из културе, књижевности и историје Француске деветнаестог века.

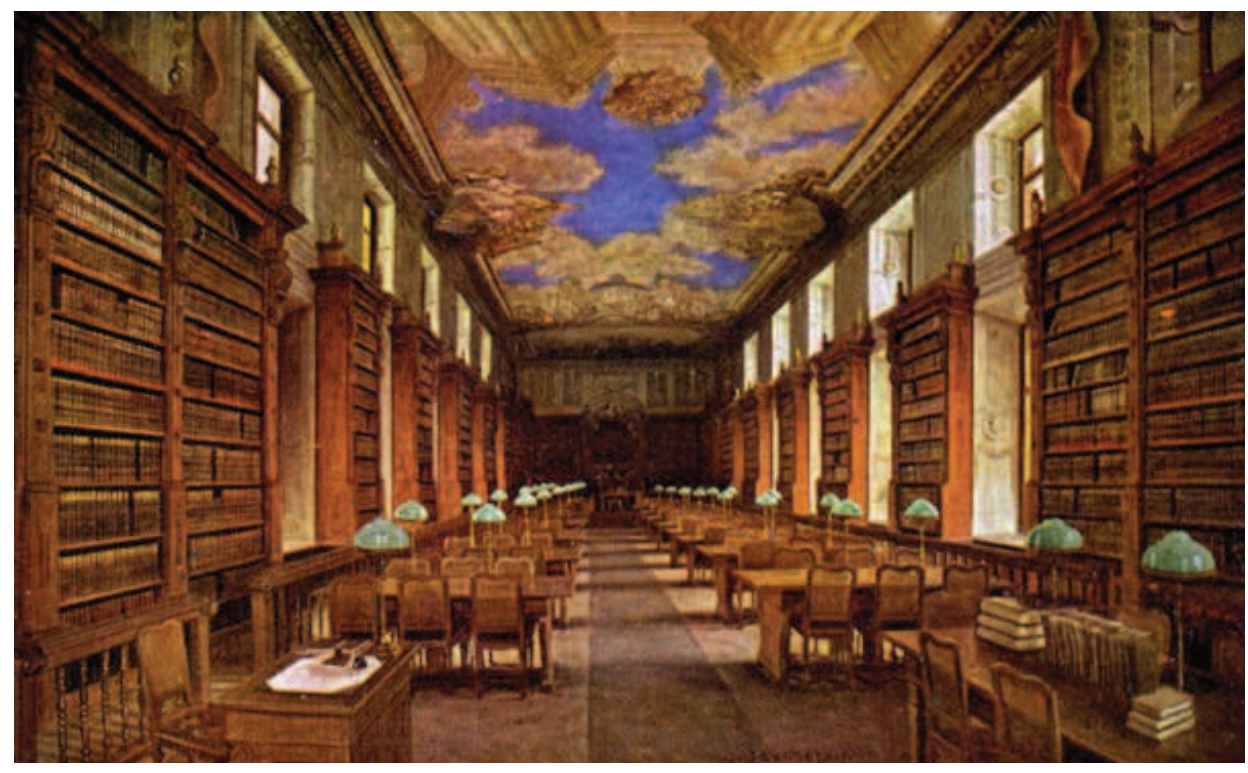

\section{Универзитетска библиотека „Светозар Марковић“ - Београд}

Иако се често сумња у исправност поступка дигитализације, ради могућих манипулација и злоупотреба, потреба да се фондови библиотека представе на нов начин долази до изражаја путем транспарентности дигиталних колекција. Универзитетска библиотека 
„Светозар Марковић“ поседује репрезентативно искуство на пољу дигитализације за наше услове.

Прва целовита дигитализована збирка у Универзитетској библиотеци обухватала је рукописе из заоставштине Исидоре Секулић, а након тога скенирани су стари ћирилски рукописи, затим оријентални рукописи, успостављен је дигитални репозиторијум Phaidra и као круна процеса дигитализације, у оквиру пројекта Europeana Newspapers, дигитализоване су старе српске новине. Ово су неке најважније дигитализоване збирке, а осим тога дигитализовани су и други документи из фонда Универзитетске библиотеке „Светозар Марковић“ попут неких посебних библиотека (Јоца Вујић, Ото Кармин и др.), старе и ретке књиге за децу и младе итд.

\section{Рукописи Исидоре Секулић}

После смрти Исидоре Секулић, у априлу 1958. године, њена лична библиотека, намештај, рукописи и уметничке слике предати су Универзитетској библиотеци „Светозар Марковић“ у Београду према личној жељи познате српске књижевнице.

Библиотека Исидоре Секулић садржи књиге из књижевности и књижевне критике, као и рукописе. Спомен соба се налази у читаоници Одељења реткости.

Од 2008. године на сајту Универзитетске библиотеке „Светозар Марковић“ може се наћи дигитализована рукописна заоставштина Исидоре Секулић. Збирка садржи 216 дигиталних докумената са укупно 3034 стране.

Најстарији рукопис је из 1919. године.

\section{Стари ћирилски рукописи}

Универзитетска библиотека поседује 90 ћирилских рукописа насталих у периоду од тринаестог до осамнаестог века. Садржај рукописа је углавном црквени, али има и световних садржаја, као што је Теодосијева похвала светом Симеуну, Косовски бој, Душанов законик и др. Када говоримо о црквеном садржају то су углавном јеванђеља, минеји, псалтири или молитвеници.

Најстарији рукопис, који потиче из тринаестог века, је псалтир писан на пергаменту, а највећи број рукописа је настао у четрнаестом и петнаестом веку. 


\section{Оријентални рукописи}

Збирка рукописа на оријенталним језицима садржи 397 рукописа у 633 књиге. Највише је рукописа на арапском (498 књига), затим на османском (126 књига) и персијском језику (9 књига). Настали су углавном на територији Србије и обухватају области историје, филозофије, права, књижевности итд.

Најстарији рукопис датира из 1206. године.

\section{Phaidra}

Дигитални репозиторијум Универзитета у Београду - PHAIDRA користи се за похрањивање радова наставника и сарадника Универзитета, при чему се објекти који су похрањени претражују и користе у складу са лиценцом коју одабере власник ауторског права.

Приступ је доступан свим члановима Универзитета (наставницима и студентима), а претраживање је слободно за све кориснике интернета без пријаве. Сви објекти имају трајни линк доступан широм света који се може цитирати или послати даље.

PHAIDRA је организована као систем за дугорочно архивирање на једноставан начин, подржава формате који су погодни за трајно похрањивање тако да је постигнута и интероперабилност са другим системима. Сачувани су подаци потребни за истраживачки, наставни и организациони рад на Универзитету у Београду.

Дигитални репозиторијум PHAIDRA успостављен је у оквиру Темпус пројекта „Нови библиотечки сервиси на универзитетима Западног Балкана", а његову програмску основу чини систем PHAIDRA Универзитета у Бечу.

\section{Дигитализоване историјске новине}

Периодика је богат извор информација из историје, културе уметности, политике и свеукупности људског живота кроз деценије.

У оквиру пројекта Новине Еуропеане (Europeana Newspapers) Универзитетска библиотека дигитализовала је скоро 400.000 страница историјских новинских текстова на српском језику и ћирилићном писму који обухвата период од почетка деветнаестог до тридесетих година двадесетог века. Колекција обухвата 45 наслова новина попут Београдских општинских новина, Нове искре, Гласа народа, 
Србадије, Зоре... За ове новине Универзитетска библиотека „Светозар Марковић“ је доставила метаподатке тако да је ово у потпуности претражива колекција.

Посебна пажња у оквиру пројекта је на новинама издатим у току Првог светског рата („Еуропеана колекција 1914-1918“).

\section{Закључак}

Дигитализација публикација је процес који нас уводи у дигиталну библиотеку и подручје очувања дигиталне грађе. Данас, многе библиотеке теже да постану дигиталне и направе отворен приступ својих збирки за што већи број корисника. Тренд креирања дигиталних библиотека у свету се огледа у настојању информационих стручњака да употребом нових технологија заинтересују и освоје тржиште Интернета својим колекцијама. Очување дигиталне грађе је дугорочни процес, а представља важан сегмент свих културних и образовних институција које ће градити своје дигиталне збирке и неопходно је посматрати га као глобално питање које ће веома брзо постати актуелно и у Србији. Анализе и истраживања дигиталних библиотека и очување дигиталне грађе су фазе које нам тек предстоје и упозоравају информационе стручњаке да редовно прате развој нових технологиија. Према овој проблематици је потребно успоставити другачији однос, такође и ујединити захтеве свих, а првенствено научних и културних институција.

\section{Литература}

Porubović-Vidović, Olivera: Digitalizacija - izazov današnjice, potreba budućnosti, u: Arhiv - časopis arhiva Jugoslavije, Br. 2, 2001, str. 50-60.

Stančić, Hrvoje: Digitalizacija, Zavod za informacijske studije, Zagreb, 2009.

Cvetana, Krstev, Digitalne biblioteke - razgraničenje pojmova, INFOTEKA br.1-2/2002

Vesna Injac, Digitalne biblioteka u svetu (http://elib.mi.sanu.ac.rs/files/journals/ncd/1/ d004download.pdf)

Crawford, W. i Gorman, M.: Future libraries: dreams, madness and reality. - New York, American Library Association Editions, 1995, str. 122.

David Stern, editor: Digital libraries: philosophies, technical design considerations and examples scenarios.- Binghamton, The Haworth Press, 1999.- str. 1. 


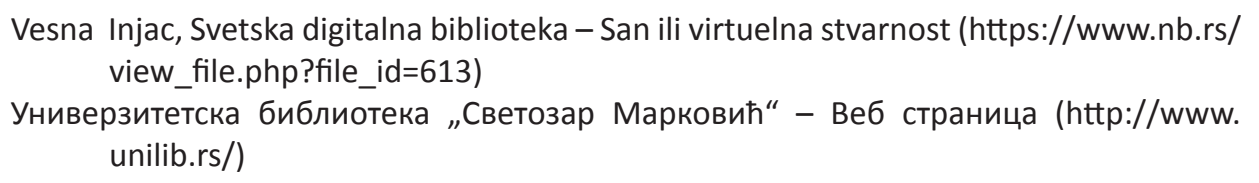

\section{Oja Krinulovic \\ Mile Stijepovic}

University library "Svetozar Markovic", Belgrade

\section{DIGITAL LIBRARIES - LIBRARIES OF THE FUTURE}

\section{Summary}

Digital libraries are one of the most actual topics for discussion about the future of libraries in the 21st century. A significant number of the world's leading libraries have digitized many valuable collections of its funds. Given the rapid development of digital libraries, the question of survival of the traditional libraries arises. There is a group of theorists who believes that today's libraries will completely disappear and be replaced by virtual digital libraries that are going to be available 24 hours a day, 7 days a week via the Internet. This would mean that libraries may completely change their shape and function from "the house of knowledge" into "the sea of information". The main idea of world libraries is that their electronic digital collections made available via the Internet, in order to be available around the world to each user, and mostly free. The University Library "Svetozar Markovic" in Belgrade also joined the process of digitization. The first was digitized the collection of manuscripts from legacy of Serbian writer Isidora Sekulic, and then the old Cyrillic manuscripts. In addition, it was created a digital repository of Belgrade University - Phaidra, and also was given a great contribution to the international projects. One of these projects is crowned by digitizing old

Serbian newspapers within Europeana Newspapers project in which the University Library submitted metadata for more than 400,000 digitized newspapers pages in Cyrillic letter. All developed countries tend to its rich library funds digitize and make accessible to as many users. Despite the limited material resources, libraries in Serbia are investing more efforts in order to include themselves in these new trends and the availabilities of the universal cultural treasures of mankind.

Key words: digital libraries, digitization, e-books, the University library „Svetozar Markovic", libraries of the future 